\title{
PENGARUH JENIS SAMPAH, VARIASI UMUR SAMPAH TERHADAP LAJU INFILTRASI LUBANG RESAPAN BIOPORI (LRB)
}

\author{
Ananda Wulida Habibiyah ${ }^{1)}$, Sri Widyastuti ${ }^{2)}$ \\ Program Studi Teknik Lingkungan Fakultas Teknik Sipil dan Perencanan ${ }^{1}$ \\ Email : anandawulida@gmail.com ${ }^{1)}$ \\ Pengajar Program Studi Teknik Lingkungan Fakultas Teknik Sipil dan Perencanan ${ }^{2)}$ \\ Universitas PGRI AdiBuana Surabaya \\ Email : rafirudi@yahoo.co.id ${ }^{2)}$
}

\begin{abstract}
Abstrak
Lubang resapan biopori digunakan sebagai tempat untuk menampung dan meresapkan air permukaan agar tidak menjadi banjir dan menjadi cadangan air tanah. Penelitian ini bertujuan untuk menentukan laju Infiltrasi air pada lubang biopori berdasarkan variasi umur dan jenis sampah. Penelitian dilakukan di Fakultas Teknik Universitas PGRI Adi Buana Jl. Dukuh Menanggal XII Surabaya. Variabel yang digunakan adalah variasi umur sampah dan jenis sampah. Jenis sampah yang digunakan meliputi sampah organik yaitu sampah daun, sampah kantin dan sampah campuran yang terdiri sampah daun dan sampah kantin. Pengamatan umur sampah dilakukan pada hari ke-7 sampai dengan hari ke-21. Dimensi lubang biopori dibuat dengan kedalaman $80 \mathrm{~cm}$, dan diameter 7,7 cm. Jarak antar lubang adalah $100 \mathrm{~cm}$. Hasil penelitian adalah jenis sampah dapat mempengaruhi laju infiltrasi pada Lubang Resapan Biopori (LRB). Sampah yang paling besar dalam meresapkan air adalah pada jenis sampah sisa makanan kantin, dengan nilai laju infiltrasi sebesar 0,0126 l/s dengan umur sampah hari ke - 16. Lubang Resapan biopori (LRB) sampah sisa makanan kantin memberikan tingkat keefektifan yang cukup signifikan terhadap blangko dalam meresapkan air mencapai rata-rata $62,5 \%$.
\end{abstract}

Kata Kunci : lubang resapan biopori, jenis sampah,umur sampah, laju infiltrasi

\begin{abstract}
Biopores infiltration pit used as a place to accommodate and absorb water surface so as not to become a flood, can seep into the soil and into groundwater reserves. This study aims to determine the rate of infiltration of water in the hole biopori based variation age and type of waste. The study was conducted at the Faculty of Engineering, University of PGRI Adi Buana Jl. Menanggal XII Surabaya. The variables used were age variations and types of garbage. Types of waste used include organic waste that leaves trash, waste canteen and mixed waste (waste leaves and trash of canteen), while the age of garbage during the 7 day until 21 day Dimensions biopores of $80 \mathrm{~cm}$, and the diameter $7.7 \mathrm{~cm}$. The distance between the holes is $100 \mathrm{~cm}$. Results of the research is the type of waste can affect the rate of infiltration at Biopores Infiltration Hole (LRB). The biggest trash in the water is the kind of junk leftover waste canteen, with a value of infiltration rate of $0.01261 / \mathrm{s}$ with the age of the waste day - 16. Biopores Infiltration Hole (LRB) provide a significant level of effectiveness against a blank in the steep water reaches an average of up to $62.5 \%$.
\end{abstract}

Keywords: biopores infiltration hole, infiltration rate, type of garbage, age of the waste

\section{PENDAHULUAN}

Perubahan porsi air hujan yang menjadi aliran permukaan menjadi pemicu utama terjadinya banjir dan selain itu buruknya saluran drainase dapat mengakibatkan banjir. Sebagian besar air hujan yang turun ke bumi tidak dapat meresap 
secara langsung ke dalam tanah dan akhirnya menjadi air permukaan.

Salah satu usaha dalam meningkatkan kemampuan tanah untuk meresapkan air hujan adalah melalui teknologi lubang resapan biopori. Menurut Brata (2008) biopori merupakan ruang atau pori dalam tanah yang dibentuk oleh makhluk hidup, seperti mikroorganisme tanah dan akar tanaman. Bentuk biopori menyerupai liang (terowongan kecil) di dalam tanah dan bercabang cabang dan sangat efektif untuk menyalurkan air dan udara ke dalam tanah. Liang pori terbentuk oleh adanya pertumbuhan dan perkembangan akar tanaman, serta aktivitas fauna tanah seperti cacing tanah, rayap dan semut di dalam tanah.

Lubang biopori selain sebagai lubang untuk meresapan air hujan juga sebagai lubang untuk pengomposan. Peningkatan daya resap air pada tanah dilakukan dengan membuat lubang pada tanah dan menimbunnya dengan sampah organik untuk menghasilkan kompos. Sampah organik merupakan sumber makanan yang dibutuhkan oleh beraneka ragam biota tanah. LRB dapat mempermudah pe-manfaatan sampah organik, dengan me-masukkannya ke dalam tanah untuk menghidupi biota dalam tanah. Fauna tanah dapat memproses sampah tersebut dengan mengunyah (memperkecil ukuran) dan mencampurkan dengan mikroba tanah yang secara sinergi dapat mempercepat proses pengomposan secara alami.

Faktor yang mempengaruhi efektifitas laju infiltrasi LRB adalah jenis sampah organik dan jenis tanah. Menurut Sibarani dan Bambang (2010) bahwa variasi umur dan jenis sampah berpengaruh terhadap kinerja biopori dengan meningkatkan laju resap air. Variasi umur sampah menunjukkan angka yang berbeda untuk dua tempat penelitian yang berbeda. Untuk jenis sampah didapatkan hasil sampah kulit buah lebih efektif daripada sampah daun dan sampah sayuran. Hal ini disebabkan aroma kulit buah yang sangat kuat dan terasa manis sehingga mampu menarik lebih banyak mikroba atau hewan pengurai lain seperti cacing, semut, rayap menuju sampah. Selain itu permukaan kulit yang licin / angka kekasarannya yang sangat kecil juga berpengaruh dalam melewatkan air menjadi lebih mudah. Sedangkan massa daun jauh lebih ringan / kecil dari pada sampah sayuran kangkung yang memiliki batang yang tebal dan lebih lama untuk mengurainya. Jenis tanah dapat mem-pengaruhi jumlah dan aktivitas organisme dalam tanah. Setiap jenis tanah memiliki laju infiltrasi dan kapasitas infiltrasi yang berbeda. Laju infiltrasi diantaranya dipengaruhi oleh tekstur, struktur, dan porositas tanah. ( Yulia, Alfiansyah Yulianur, dan Sugianto3, 2014).

Penelitian ini untuk mengetahui pengaruh variasi jenis sampah dan variasi umur sampah terhadap laju infiltrasi LRB dan untuk menentukan lubang resapan biopori manakah yang efektif lebih besar dalam meresapkan air tanah berdasarkan variasi jenis sampah dan umur sampah.

\section{METODOLOGI PENELITIAN}

Populasi dalam penelitian ini adalah seluruh LRB yang ada di depan gedung Fakultas Teknik Universitas PGRI Adi Buana Surabaya, Jl. Dukuh Menanggal XII Surabaya dann sampel dalam penelitian ini adalah 9 buah LRB.

Variabel dalam penelitian ini adalah umur komposting sampah yaitu hari ke-7 sampai hari ke-21 dan jenis sampah yaitu sampah daun, sampah sisa makanan kantin dan sampah campuran (sampah daun + sampah sisa makanan kantin). Parameter pada penelitian ini adalah laju infiltrasi.

Alat dan bahan yang digunakan dalam penelitian ini adalah Lubang biopori ukuran 3 dim , bor biopori, penggaris $20 \mathrm{~cm}$, stopwatch, tandon air, semen, pasir, sampah daun dan sampah sisa makanan kantin

\section{Langkah-langkah Penelitian}

\section{A. Analisa Jenis Tanah, Porositas dan Permeabilitas}

Pengujian analisa jenis tanah, porositas dan permeabilitas dilaksanakan di Laboratorium Mekanika Tanah dan Batuan Institut Teknologi Sepuluh Nopember.

\section{B. Pengukuran Laju Infiltrasi pada Blangko}

1. Membuat lubang dengan kedalaman 80 $\mathrm{cm}$ tentang jenis sampah dan berdiameter $7,7 \mathrm{~cm}$ dengan menggunakan bor.

2. Memasukkan pipa pvc kedalam tanah, diatas lubang diletakkan pipa pvc tambahan dengan ukuran $20 \mathrm{~cm}$

3. Kemudian memasukkan air ke dalam LRB sampai penuh \pm 231 . 
4. Menyalakan stopwatch pada saat air memenuhi LRB.

5. Mematikan stopwatch pada saat air mengalami infiltrasi sehingga permukaan air dalam LRB rata dengan permukaan tanah.

6.

\section{Pengukuran Laju Infiltrasi pada LRB}

1. Membuat lubang dengan kedalaman 80 $\mathrm{cm}$ dan berdiameter $7,7 \mathrm{~cm}$ dengan menggunakan alat bor, jarak antar lubang $100 \mathrm{~cm}$.

2. Memasukkan pipa pvc kedalam tanah, diatas lubang diletakkan pipa pvc tambahan dengan ukuran $20 \mathrm{~cm}$.

3. Bibir lubang diperkuat dengan semen dan pasir.

4. Mengisi lubang biopori dengan sampah organik yang di variasi yaitu sampah daun, sampah sisa makanan kantin dan sampah campuran (sampah daun + sampah sisa makanan kantin, hingga penuh.

5. Setelah hari ke-7 sampai dengan hari ke21 pada setiap lubang biopori diuji laju infiltrasi dengan cara memasukkan air ke dalam LRB sampai penuh \pm 231 .

6. Menyalakan stopwatch pada saat air memenuhi LRB.

7. Mematikan stopwatch pada saat air mengalami infiltrasi sehingga permukaan air dalam LRB rata dengan permukaan tanah.

Penelitian ini adalah penelitian eksperimen dengan rancangan penelitian seperti pada gambar 1 berikut :

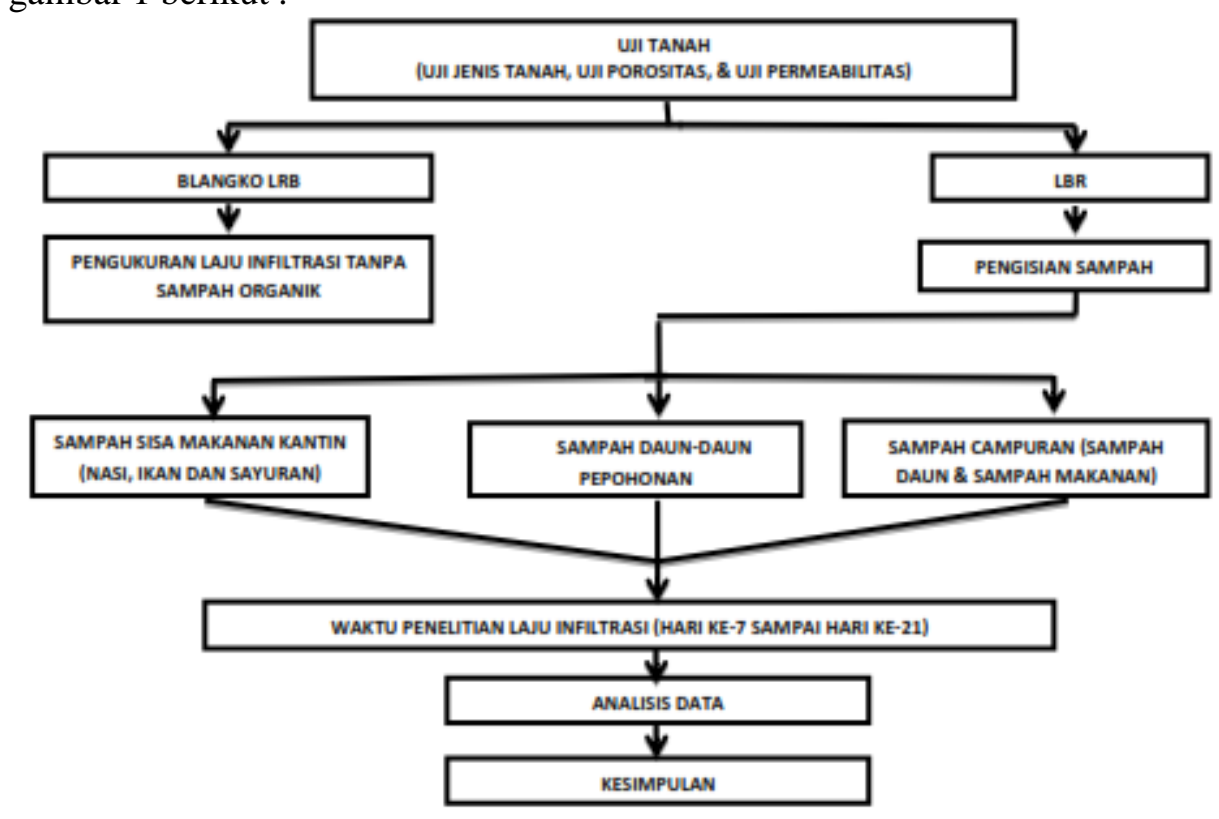

Gambar 1. Rancangan Penelitian LRB

\section{HASIL PENELITIAN DAN PEMBAHASAN}

\section{A. Hasil Analisis Jenis Tanah}

Pengujian tanah di kampus II Universitas PGRI Adi Buana Surabaya diperoleh hasil sebagai berikut : kerikil = $16,61 \%$, pasir $=62,3 \%$, butiran halus
$($ Lanau + Lempung $)=21,03 \%$. Jenis tanah pada penelitian ini adalah pasir lanau berwarna coklat. Hasil Uji Porositas (n) adalah sebesar $38.12 \%$ dan permeabilitas (k) sebesar $8.97 \mathrm{E}-04 \mathrm{~cm} / \mathrm{det}$

\section{B. Laju Infiltrasi}

Laju infiltrasi blangko, LRB sampah daun, LRB sampah sisa makanan kantin dan LRB 
sampah campuran (sampah daun \& sampah sisa makanan kantin) hasilnya dapat dilihat pada tabel 1 berikut

C.Pengaruh Jenis Sampah dan Variasi Tabel 1. Laju Ir Umur LSampah Terhadap Laju Infitrasi

\begin{tabular}{|c|c|c|c|c|c|c|c|c|c|c|}
\hline$(\mathrm{cm})$ & $(\mathrm{cm})$ & $\begin{array}{l}\text { Umur Sampah } \\
\text { Hari Ke- }\end{array}$ & $\begin{array}{c}\text { V LRB } \\
\text { Sampah } \\
\text { Daun } \\
(1 / s) \\
\end{array}$ & $\begin{array}{c}\text { VLRB } \\
\text { Sampah } \\
\text { Makanan } \\
\text { Kantin } \\
\text { (U/s) }\end{array}$ & $\begin{array}{c}\text { V URB } \\
\text { Sampah } \\
\text { Campuran } \\
\text { [U/s] }\end{array}$ & $\begin{array}{c}\text { LRB } \\
\text { Blaneloo } \\
(U / s) \\
\end{array}$ & $\begin{array}{c}\text { Tineksit } \\
\text { Efelatifitas } \\
\text { Sampah } \\
\text { Daun } \\
\text { Pengaruh }\end{array}$ & $\begin{array}{l}\text { Tinelate } \\
\text { Efektifitas } \\
\text { Sampah } \\
\text { atranan Kantin } \\
\text { jenis Sam }\end{array}$ & $\begin{array}{c}\text { Tingikat } \\
\text { Efektifitas } \\
\text { Sampah } \\
\text { Campuran } \\
\text { ipahisdan }\end{array}$ & variasi \\
\hline 7,7 & 80 & 7 & 0,007 & 0,009 & 0,009 & \multirow{2}{*}{\multicolumn{5}{|c|}{ umür sampah terhạdap laju infitiâsi LRB }} \\
\hline 7,7 & $\mathbf{s o}$ & $\mathbf{g}$ & 0,007 & 0.009 & 0.009 & & & & & \\
\hline 7,7 & 80 & 9 & 0,007 & 0,009 & 0,009 & \multicolumn{5}{|c|}{ dapat dilihat pada gambar $2: 30,102$} \\
\hline 7,7 & $\mathbf{s o}$ & 10 & 0,007 & 0.010 & 0.009 & 0,007 & 13,000 & 93,514, & 30,475 & \\
\hline 7,7 & $\mathbf{s o}$ & 11 & 0,007 & Q.010 & 0.008 & 0,007 & 0,901 & 00,130 & 28,507 & \\
\hline 7,7 & 80 & 12 & 0,007 & Q.010 & 0,009 & 0,007 & 12,253 & 00,150 & 42,237 & \\
\hline 7,7 & so & 13 & 0,008 & a.011 & Q.010 & 0,007 & 18,994 & 70,400 & 48,091 & \\
\hline 7,7 & $\mathbf{s o}$ & 14 & 0,008 & 0.010 & 0.010 & 0,007 & 21,541 & 38,304 & 51,064 & \\
\hline 7,7 & $\mathbf{s o}$ & 15 & 0,008 & 0.012 & 0.010 & 0,007 & 17,033 & 83,220 & 25,191 & \\
\hline 7,7 & $\mathbf{s o}$ & 10 & 0,008 & 0,013 & Q.010 & 0,007 & 17,194 & 91,892 & 40,392 & \\
\hline 7,7 & $\mathbf{s o}$ & 17 & 0,008 & 0.012 & 0.010 & 0,007 & 17,842 & 82,001 & 30,018 & \\
\hline 7,7 & so & 18 & 0,008 & 0.012 & 0,011 & 0,007 & 25,479 & 80,508 & 02,900 & \\
\hline 7,7 & $\mathbf{s o}$ & 19 & 0,007 & 0.011 & 0.010 & 0,007 & 12,105 & 74.233 & $\infty, 1>0$ & \\
\hline 7,7 & $\mathbf{s o}$ & 20 & 0,007 & 0.011 & 0.010 & 0,007 & 8,535 & $\infty 0,735$ & 49,474 & \\
\hline 7.7 & $\mathbf{8 0}$ & 21 & 0,007 & 0.010 & 0,009 & 0,007 & 5,005 & 46.897 & 34,997 & \\
\hline \multicolumn{2}{|c|}{ Rata - rata } & & 0,007 & 0.011 & 0.010 & 0.007 & 13,951 & 02.505 & 45,125 & \\
\hline
\end{tabular}

Berdasarkan tabel 1 dapat dilihat bahwa LRB sampah daun, LRB sampah sisa makanan kantin dan LRB sampah campuran (sampah daun \& sampah sisa makanan kantin) ketiganya dapat meningkatkan laju infiltrasi air tanah, tetapi yang paling baik meningkatkan laju infiltrasi air tanah adalah LRB sampah sisa makanan kantin dengan rata-rata kenaikan $62,5 \%$. 


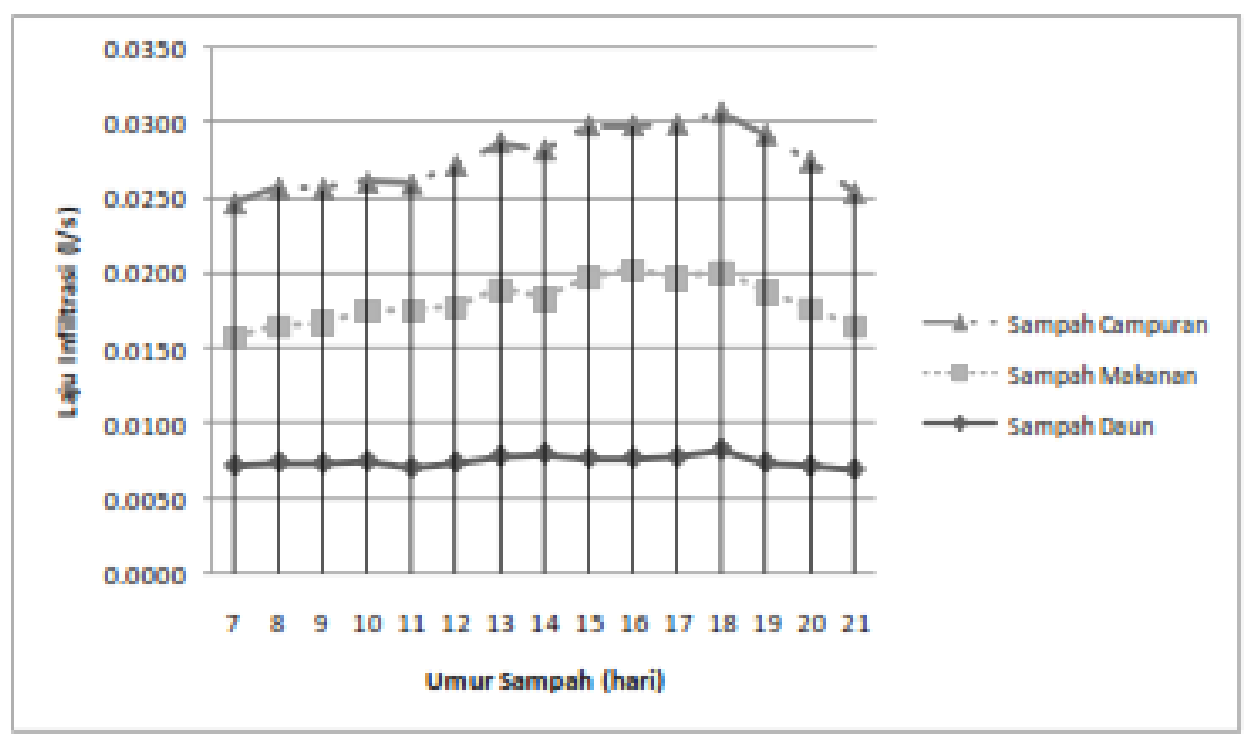

Gambar 2. Laiu Infiltrasi LRB

Dari data ini didapatkan hasil laju infiltrasi yang berbeda-beda pada setiap jenis sampah. Hal ini disebabkan karena jumlah air yang meresap tergantung dari proses pembentukan biopori pada setiap jenis sampah. Biopori ini terbentuk sebagai hasil dari aktifitas mikroorganisme dalam menguraikan/mendegradasi sampah. Dimana diketahui bahwa bila semakin banyak mikroorganisme, maka biopori yang terbentuk juga akan semakin banyak, sehingga jumlah air yang mampu diresapkan pun akan semakin banyak. Sebaliknya jika jumlah biopori dalam tanah yang terbentuk sedikit, maka jumlah air yang dapat diresapkan pun akan semakin kecil.

Laju infiltrasi LRB sampah sisa makanan kantin memberikan nilai yang paling besar dibandingkan laju infiltrasi LRB sampah daun dan LRB sampah campuran. Hal ini dapat disebabkan karena pada sampah sisa makanan kantin seperti

\section{Efektifitas Kenaikan Laju Infiltrasi}

Kenaikkan laju infiltrasi LRB dapat dilihat pada gambar 3 berikut ikan, tulang, nasi dan sayur mengandung kandungan karbohidrat, protein, lemak yang disenangi mikroba sehingga jenis mikroba yang dihasilkan menjadi lebih banyak seperti mikroba pengurai karbohidrat/selulosa, mikroba proteolitik, mikroba lipolitik serta hewan pengurai lainnya seperti cacing, semut dsb menuju sampah atau dengan kata lain sampah sisa makanan kantin lebih disukai organisme tanah karena lebih mudah hancur dibandingkan dengan sampah lainnya.

Pola gambar 2 menunjukkan bahwa nilai laju infiltrasi meningkat dari hari ke hari, selanjutnya mengalami penurunan. Peningkatan nilai laju infiltrasi LRB diakibatkan oleh aktifitas fauna tanah yang semakin meningkat karena sumber makanan (sampah organik) masih tersedia, sehingga biopori yang tercipta semakin banyak. Sedangkan penurunan nilai laju infiltrasi LRB Pada hari ke - 17 sampai hari ke - 21 mengalami penurunan nilai laju infiltrasi karena aktifitas fauna tanah menurun, karena sampah organik segar yang tersedia semakin sedikit 


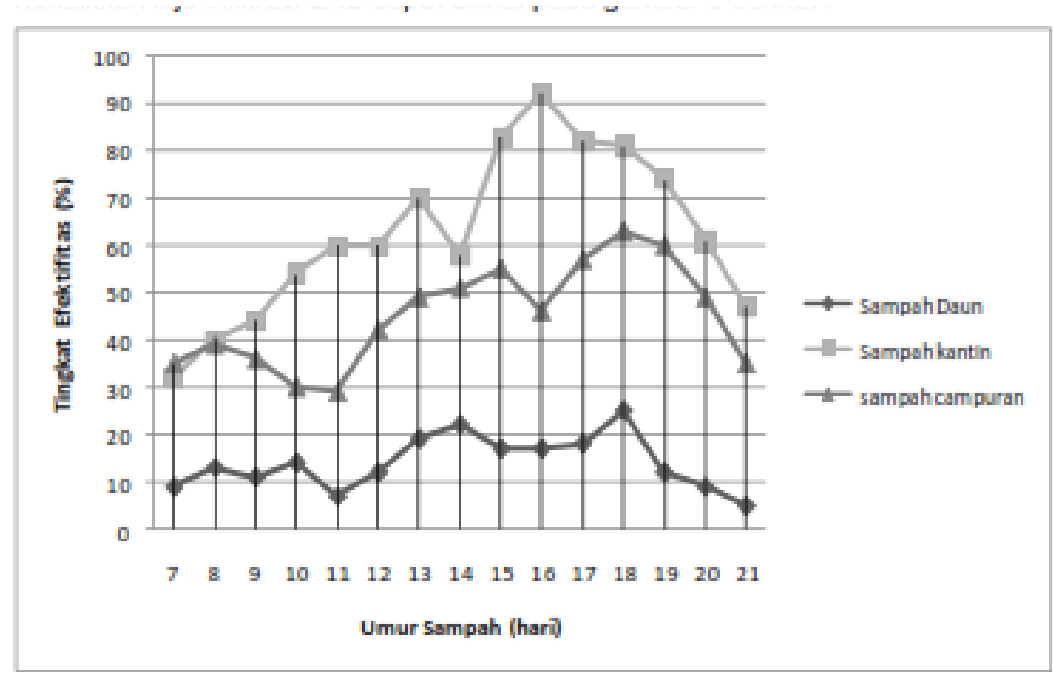

Gambar 3. Efektifitas Kenaikan Laju Infiltrasi

Dari gambar 3 dapat dilihat bahwa kenaikan laju infiltrasi yang paling baik adalah LRB sampah sisa makanan kantin dengan waktu komposting selama 16 hari. Dengan kata lain LRB tersebut dikatakan sebagai LRB ideal. Hal ini dapat disebabkan karena sampah sisa makanan kantin yang memiliki nisbah $\mathrm{C} / \mathrm{N}$ yang rendah, lebih disukai organisme tanah karena lebih mudah hancur.

\section{KESIMPULAN}

Penelitian ini dapat disimpulkan bahwa : 1) Jenis sampah dapat mempengaruhi besar/kecilnya laju infiltrasi pada LRB, Jenis sampah yang paling besar dalam meresapkan air adalah pada jenis sampah sisa makanan kantin, dengan nilai laju infiltrasi yang dihasilkan sebesar $0,013 \mathrm{l} / \mathrm{s}$ pada jenis tanah pasir lanau berwarna coklat, dengan porositas sebesar $38,12 \%$ dan permeabilitas (k) sebesar 8.97E-04 cm/det. 2) LRB yang ideal/efektif meresapkan air ke dalam tanah untuk variasi umur sampah adalah LRB dengan umur sampah hari ke - 16. 3) LRB sampah sisa makanan kantin dengan waktu pengomposan 16 hari, memberikan tingkat keefektifan yang cukup signifikan terhadap blangko dalam meresapkan air mencapai rata-rata 62,5\%.

\section{SARAN}

Saran dari penelitian ini adalah 1) Perlunya mensosialisasikan dan enerapkan biopori dilingkungan sekitar sebagai upaya untuk mensukseskan penerapan biopori di Indonesia. Teknologi biopori ini sangat bermanfaat bagi masyarakat dan lingkungan, karena dapat meminimalisir banjir yang menggenangi kota-kota di Indonesia, khususnya dikota-kota yang lahannya kritis (meningkatkan daya resap air dan cadangan air tanah), mengubah sampah organik menjadi kompos, mengurangi emisi $\mathrm{Co} 2$ dan metan (CH4), serta dapat mengatasi penyebab penyakit yang ditimbulkan oleh adanya genangan air. 2) Perlunya dilakukan penelitian lebih lanjut mengenai Lubang resapan Biopori (LRB) dengan variasi jenis sampah yang berbeda-beda, karena berhasilnya atau efektifnya biopori juga tergantung dari beberapa faktor yang mempengaruhinya seperti jenis tanah, jenis sampah organik, umur sampah dan level muka air tanah. 3) Dilakukan penelitian tentang jenis mikroba dekomposer yang ada di dalam lubang biopori, sehingga bisa diketahui jenis mikroba yang terlibat dalam proses pengkomposan. Untuk selanjutnya. mikroba tersebut dapat diseleksi menjadi mikroba yang efektif untuk mempercepat menguraikan sampah organik. 


\section{DAFTAR PUSTAKA}

Bambang, D dan Sibarani, R. T. 2009. Penelitian Biopori Untuk Menentukan Laju Resap Air Berdasarkan Variasi Umur dan Jenis Sampah. Jurusan Teknik Lingkungan FTSP. ITS - Surabaya Brata, Kamir R 2008. Lubang

Resapan Biopori. Jurusan tanah Fakultas Pertanian IPB. Bogor.

Brata, Kamir R dan Anne Nelistya, 2008. Lubang Resapan Biopori, Bogor. C. D. Soemarto, 1999, Hidrologi

Teknik, Penerbit Erlangga, Jakarta http://erabaru.or.id/2008. Biopori Teknologi Solusi Banjir. diunduh tanggal 15 Desember 2014.

Johnherf, 2008. Biopori Sebagai Peresap Air yang Mengatasi Banjir dan Sampah,

URL:http://johnherf.wordpress.com/2008/0 2/21/biopori-sebagai-peresap-air-yang- mengatasi-banjir-dan-sampah/ diunduh tanggal 15 Desember 2014.

Notohadiprawiro, T. 1999. Tanah dan Lingkungan. Direktorat Jenderal Pendidikan Tinggi Departemen Pendidikan dan Kebudayaaan.

Rauf,A.2009.Optimalisasi engelolaan Lahan Pertanian Hubungannya dengan Upaya Memitigasi Banjir. USU. Medan Widyastuti, Sri . 2013. Perbandingan Jenis Sampah Terhadap Lama Waktu Pengomposan Dalam Lubang Resapan Biopori. Surabaya.Laporan Penelitian Yulia, Alfiansyah Yulianur, Sugianto, 2014, Jurnal Teknik Sipil Pascasarjana Universitas Syiah Kuala Volume 3, No. 3, Agustus 2014 - 138ISSN 2302-0253 halaman 138- 147 http://prodipps.unsyiah.ac.id/Jurnalmts/imag es/Jurnal/volume/vol3/3.3.mts/14.138.147.Y ulia.pdf 